\title{
EFFICIENCY OF USING ECONOMIC AND STATISTICAL METHODS IN ANALYSIS AND MANAGEMENT OF COMMODITY INVENTORIES
}

\author{
Rybalko O. M., Varlamova I. S., Nazarchuk D. \\ Zaporizhzhia National University \\ Ukraine, 69600, Zaporizhzhia, Zhukovsky str., 66 \\ Irina.varlamova.zp@gmail.com \\ ORCID 0000-0003-0757-1730, ORCID 0000-0002-9921-327
}

Key words:

inventories, competitiveness, effective control, analysis, economic and statistical research, trade enterprise, turnover.
In the given article problems of stock management and procedure of carrying out the analysis of commodity stocks with use of economic and statistical methods at the trading enterprise were considered. Methods of economic and statistical research - the concept is very broad and has a wide range. This general term covers a range of modern scientific approaches, methods, tools, methods of measurement, formalized description, analysis and forecasting of economic phenomena and processes inherent in the financial, investment, tax system, and therefore in modern economic development, business activities of commercial enterprises, which must maintain competitiveness, reliable and profitable operation in the long run, largely depends on their ability to meet the needs of a personal nature, as modern consumers and have the ability to increase their own turnover. To achieve this goal, trading companies must be able to maintain the necessary turnover of goods, provide the necessary range and quality of inventories, to effectively control the use and management in this process, which ensures the profit and efficiency of the enterprise. Thus, the relevance lies in the answers to the following questions: "How to skillfully implement the analysis of inventories and the effectiveness of their use in commercial enterprises, which will ensure effective control and management decisions in terms of this issue?" affects the financial condition of commercial enterprises, because the presence or absence of stocks leads to both costs and revenues.

\section{ЕФЕКТИВНІСТЬ ВИКОРИСТАННЯ ЕКОНОМІКО-СТАТИСТИЧНИХ МЕТОДІВ В АНАЛІЗІ ТА УПРАВЛІННІ ТОВАРНИМИ ЗАПАСАМИ ТОРГОВОГО ПІДПРИЕМСТВА}

\author{
Рибалко О. М., Варламова І. С., Назарчук Д. О. \\ Запорізький начіональний університет \\ Україна, 69600, м. Запоріжжя, вул. Жуковського, 66
}

\begin{abstract}
Ключові слова:
товарні запаси, конкурентоспроможність, ефективний контроль, аналіз, економікостатистичні дослідження, торгівельне підприємство, товарообіг.
\end{abstract}

У поданій статті були розглянуті проблематика управління запасами та процедура проведення аналізу товарних запасів з використанням економікостатистичних методів на торговому підприємстві. Методи економікостатистичних досліджень - поняття дуже широке і має великий спектр. Цим загальним терміном охоплюється цілий комплекс використання сучасних наукових підходів, методів, інструментів, способів вимірювання, формалізованого опису, аналізу та прогнозування економічних явищ $\mathrm{i}$ процесів, властивих фінансовій, інвестиційній, податковій системі, а тому в сучасних умовах економічного розвитку, ведення господарської діяльності торгівельних підприємств, що повинні підтримувати конкурентоспроможність, надійне та рентабельне функціонування у довгостроковій перспективі, багато в чому напряму залежить від їх можливості задовольняти потреби особистого характеру, як сучасних споживачів та мати здатність для збільшення обсягів власного товарообороту. Для досягнення цієї мети торгівельні підприємства повинні мати змогу підтримувати необхідні оберти реалізації товару, забезпечити необхідний асортимент та якість товарних запасів, здійснювати ефективний контроль користування та управління в цьому процесі, що забезпечує прибуток й ефективність функціонування підприємства. Таким чином актуальність полягає у відповідях на такі запитання: «Як вправно реалізувати аналіз товарних запасів та ефективність їх використання на торгівельних підприємствах, які дозволять забезпечити ефективний контроль та прийняття управлінських рішень 3 точки зору цієї проблематики?», бо як відомо правильне управління товарними запасами суттєво впливає на фінансовий стан торгових підприємств, тому що наявність або відсутність запасів веде за собою і витрати, і доходи. 


\section{Formulation of the problem}

One of the most important factors in improving the efficiency of trade enterprises is the provision of their stocks and resources in the required quantity and structure and their fuller use. Market relations involve competition between different trade organizations, which can be won by those who most effectively use all types of available stocks.

Inventories of commercial enterprises occupy the largest share in the value of assets and are the main source of replenishment of own funds. However, inventories are the main object of daily control.

In commercial enterprises, all stocks of goods that are formed are divided into three groups:

1) stocks of current storage;

2) stocks of seasonal storage and early delivery;

3) stocks of special purpose [7].

Inventories of current storage make up the bulk of all inventories of the trading company. They are created to ensure uninterrupted trade in the current period and must be constantly replenished.

Inventories of seasonal storage and early delivery are created only mainly in large universal trade enterprises, based on the characteristics of the range of goods sold by them or the geographical location of such enterprises.

Commodity stocks of special purpose are created at trade enterprises to ensure certain purposes not related to the current sale of goods (for example, for employees of the river and navy are created stocks of special work clothes or to issue commodity winnings in lotteries, etc.) [5, p. .197].

The main purpose of inventory management of the enterprise is to ensure uninterrupted supply of products in the required quantity and set deadlines and achieve on this basis the full realization of production with minimal costs for the maintenance of stocks.

The essence of inventories at commercial enterprises involves the availability of purchased and paid goods in warehouses, warehouses, storage facilities, etc. that are available to the owner of the retail chain, the largest share of which are inventories of current storage.

Standards of inventories are developed quarterly in the amount and days before turnover. They are determined both in general by the trading company and by product groups, as well as stores and other units of the retail network. In the same context, the analysis of inventories. In this case, inventories are taken at retail prices, ie sales prices, which show the volume of turnover [2].

The issues of proper and effective analysis of inventories become especially relevant in the business life of a trading company, which are identified in the needs of optimizing their composition and structure. In order to address these issues, there is a need for in-depth research and practical use of both economic and statistical methods in the analysis.

The purpose of inventory analysis is to identify potential opportunities for their rational formation and increase efficiency [3].

\section{Analysis of recent studies and publications}

The analysis of literature sources on the analysis of inventories showed that it is given a lot of attention by experts in the field of economics, accounting, and other sciences. It is necessary to allocate works and publications of domestic and foreign authors, among them: I. Blank [1], F. Butynets [4], L. Frolova [6], J. Schreibfeder [8], A. D. Sheremet [9], F. Harris and others. Authors such as L. Frolova, F. Harris, J. Schreibfeder and others define the essence of inventories, considering methods and basic principles, other authors explore different approaches to the assessment of accounting, analysis and documentation, as well as suggest ways to improve them. However, they all consider certain aspects of the analysis, without linking them to a comprehensive economic and statistical analysis.

\section{Formulation of the goals of the article}

The objectives of the article are to determine the directions and consistent analysis of inventories using economic and statistical research methods to identify features and problems of inventory management of trade enterprises of Ukraine.

\section{Presentation of the main research material}

In my opinion, inventory management includes defining operational objectives of inventory management, inventory needs planning, organization of warehouse workers, placement and interaction of employees, their motivation by creating optimal working and leisure conditions, payment of appropriate wages and bonuses, communication with suppliers and consumers, control of fulfillment of orders and maintenance of stocks at the enterprise, promotion of stocks on a logistic chain for the purpose of satisfaction of needs of production and consumers of finished goods at optimum logistic expenses.

The inventory management process is a system of measures that cover the tasks of strategic analysis, financial management and marketing. The policy of inventory management of enterprises should be implemented in the following aspects [7]:

- formation of optimal accounting, tax, pricing and product policies;

- ensuring an effective system of internal control; analysis of the composition and structure of inventories;

- optimization of the structure of inventories;

- minimization of current costs for inventory maintenance;

- ensuring the efficient use of inventories.

The effectiveness of inventory management of the enterprise is determined by many factors - both external, independent of the enterprise, and internal, which the company can and should actively influence. External factors include the general state of the economic situation in the country and the region, the peculiarities and instability of tax legislation, loan terms and interest rates, the availability of targeted funding. However, no less important is the internal factors that the company must actively use to improve the efficiency of working capital [12, p. 382].

The analysis of the approaches used today by the management of Ukrainian enterprises to the management of inventories of the organization, revealed the presence of serious unresolved issues, among which are the following:

- Supply chains serve mainly production, not consumers, resulting in huge uncertainty in demand due to the large number of errors throughout the supply chain;

- Simplified forecasting methods used by most Ukrainian companies in sales planning lead to errors in forecasts, and as 
a result, to the creation of either surplus stocks or a shortage of available commodity items.

To eliminate these problems and solve the problem of improving the efficiency of inventory management, a marketing and logistics approach was developed, based on the selection of groups of inventories according to the degree of risk of non-fulfillment of the customer's order. According to the proposed approach, it is advisable to distinguish between:

- Inventories with a high degree of risk, which will be understood as inventories, characterized by significant fluctuations in demand and significant supply disruptions;

- Stocks with a medium degree of risk, which include stocks that have either a high enough forecasting accuracy, the presence of trends and seasonal fluctuations, or a high degree of availability in terms of purchasing power, which in both cases avoids non-fulfillment of customer orders;

- Stocks with a low degree of risk, which include stocks with a stable level of consumption and a fairly high reliability of suppliers.

The analysis of the three groups recommended for selection allows to establish the main reasons for the formation of inventories at the enterprise, which include:

- Mismatch of volumes of delivery of goods to volumes of one-time consumption;

- The contradiction between the continuous nature of consumption of goods and the discrete nature of their receipt at the place of consumption;

- Changes in market conditions that lead to the need to create stocks due to changes in prices;

- Seasonality of consumption processes. The main indicator by which you can assess the effectiveness of inventory management in the enterprise, is the turnover, ie the speed of turnover of goods or the time during which inventories are sold [7].

Turnover is expressed by the number of revolutions or the number of days required to make one turnover. Turnover in the number of turnovers (Arr) shows the number of revolutions carried out by the inventory during the calendar period of time [7]: Arr = OP / TZsr (1) where OP - sales in the calendar period, UAH .; TKsr - the average size of inventory in the calendar period, UAH.

Turnover in days (Obdn) shows the time during which inventories are in circulation, ie the number of days for which the average inventory rotates [7]: Obdn $=\mathrm{TZsr} * \mathrm{D} / \mathrm{OP}(2)$ where $\mathrm{D}$ is the number of days in the calendar period. The obtained values of turnover for the actual period Obfdn are compared with the values of the indicator for the previous period Obpoperdn:

- If Obfdn> Obpoperdn, then the company has insufficient stocks;

- If Obfdn <Obpoperdn, it means that inventories are either large or not in demand [7].

The results of numerous studies show that one of the reasons for the low turnover of stocks of domestic trade enterprises is the large amount of "dead" stocks. In this regard, the problem of increasing the turnover of inventories is interrelated with the problem of forming the optimal range.

One of the methods of assortment analysis, which can be used in the structuring of inventories, is the method of $\mathrm{ABC}$ analysis. $\mathrm{ABC}$ analysis - a method that allows you to classify stocks according to the degree of their importance to the organization in order to highlight their priorities in solving the problem of inventory management. The method is based on the principle of V. Pareto, which is that $20 \%$ of all goods give $80 \%$ of turnover [11].

The use of $\mathrm{ABC}$-analysis and other marketing tools in solving this problem allows you to develop measures to optimize inventories: - Highlight the most important products; Exclude from the range of goods that reduce the turnover of inventories. However, the high turnover of stocks requires a system of stricter control, which ensures optimal investment in inventories. If to ensure the effective operation of the organization it is necessary to maintain a high level of inventory turnover, then to meet the needs of its customers, the organization must have a wide range of goods that are rarely sold, which reduces the level of Obdn or Arr. Thus, the main problem of inventory management is to establish the most optimal ratio between the losses from the "freezing" of funds and the level of customer satisfaction

It is also important in the process of inventory management to determine the costs associated with inventories (Table 1). Such costs include:

- Order costs;

- Storage costs;

- Deficit costs [13].

Table 1 Characteristics of costs associated with inventory management

\begin{tabular}{|l|l|l|}
\hline Type of costs & Characteristic & Excluded costs \\
\hline Order costs & $\begin{array}{l}\text { This type of cost is associated with the } \\
\text { placement of orders and depends on } \\
\text { the frequency with which they are } \\
\text { placed }\end{array}$ & $\begin{array}{l}\text { - keeping accounting records; } \\
\text { - preparatory and final operations; } \\
\text { - transport costs for the movement of goods between } \\
\text { enterprises and warehouses }\end{array}$ \\
\hline Storage costs & $\begin{array}{l}\text { By investing in inventories, the } \\
\text { organization thus refuses to use these } \\
\text { funds for other purposes }\end{array}$ & $\begin{array}{l}\text { - the cost of capital materialized in inventories; } \\
\text { - the cost of keeping goods in stock; } \\
\text { - other costs associated with the physical presence of goods }\end{array}$ \\
\hline Cost deficits & $\begin{array}{l}\text { These costs arise when the demand for } \\
\text { a product exceeds its availability in } \\
\text { stock. One of the most commonly } \\
\text { used indicators to control deficit } \\
\text { expenditures is the level of service. }\end{array}$ & $\begin{array}{l}\text { Unearned profit if the buyer decides to buy the } \\
\text { a competing organization }\end{array}$ \\
\hline
\end{tabular}


Minimization of these costs can be used as an optimization criterion in solving the problem of inventory management. It should also be noted that economic and mathematical modeling can also be used as a tool for inventory management in a competitive market. Taking into account the problems formulated above, the process of optimal inventory management can be represented in the form of a diagram (Fig. 1).

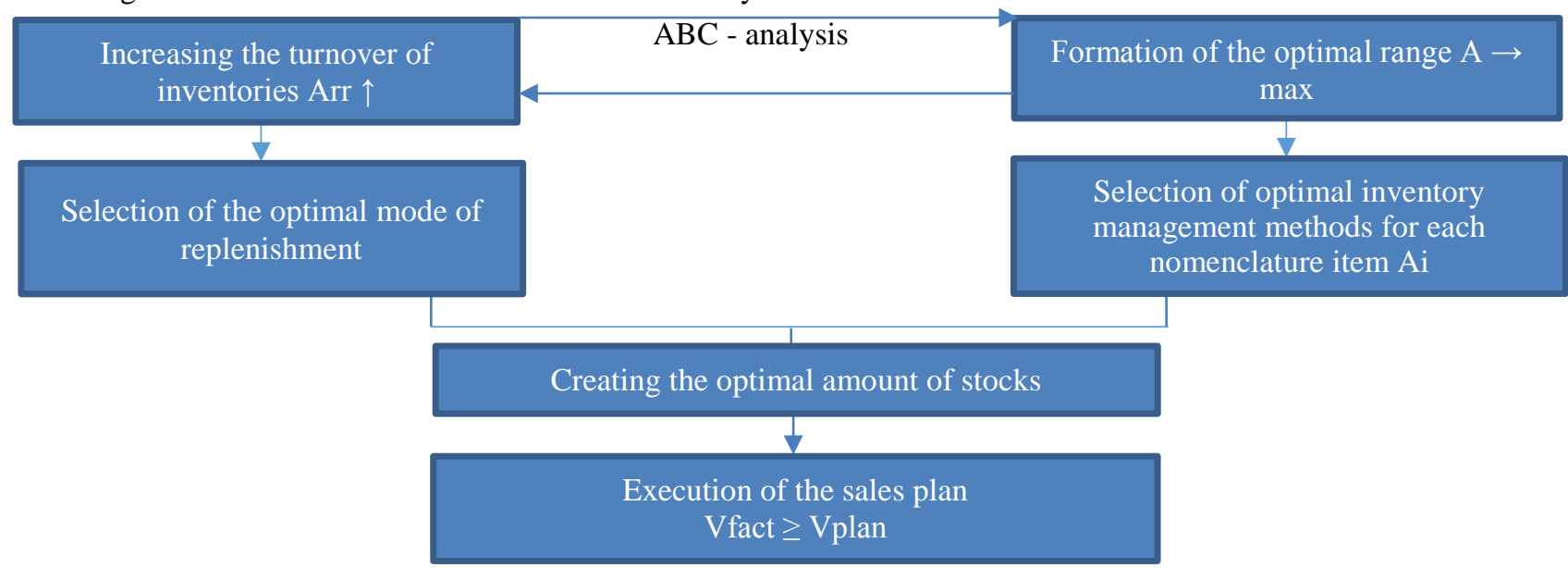

Fig.1. The process of optimal inventory management: Vfact - the actual sales of the organization in the study period, thousand UAH; Vplan - the planned sales of the organization in the study period, thousand UAH.

\section{Conclusions and prospects for further research in this area}

Proper management of inventories significantly affects the financial condition of the trading company. The presence or absence of inventories entails both income and expenses. Each company chooses a form of inventory management, based on personal needs and the current state of consumer demand. An effective mechanism for managing inventories of a commercial enterprise allows you to fully implement the goals and objectives facing it; contributes to the effective implementation of all its functions in trade enterprises.

\section{References}

1. Upravlinnia finansami pidpryiemstv: pidruchnik Blank, G.W. Sitnik, VS Andriets. - 2nd ed., Reworked. and add. Kyiv: Kyiv. nat. trade and economy University, 2017. - 792 p. [in Ukrainian].

2. Green BV Economic analysis of trade activity./ BV Green // Textbook. way. - Kyiv: Center for Educational Literature, 2011. - 392 p. [in Ukrainian].

3. Sidorova TO Improvement of methods of analysis of commodity stocks of the enterprise / T.O. Sidorova, NB Kashchena, G.G. Lysak // Economic strategy and prospects for the development of trade and services. - 2013. - Vip. 1 (1). - P. 23-30. - Access mode: http://nbuv.gov.ua/UJRN/esprstp_2013_1(1)_6 [in Ukrainian].

4. Butynets FF Financial accounting: [textbook for students majoring in "Accounting and Auditing" higher education. institutions] / F.F. Butynets. - Zhytomyr: PP "Ruta", 2002. [in Ukrainian].

5. Voskobayeva AV Strategy of inventory management / AV Voskobayeva, OS Voskobayeva. // Bulletin of ZhSTU. 2011. - № 4 (58). - P. 197-199. [in Ukrainian].

6. Frolova LV Problems of formation of commodity stocks in a commercial enterprise in conditions of instability / LV Frolova, OS Voskobayeva. // Trade and

7. Harris F. W. «How Many Parts To Make At Once» Factory / Harris F. W. // The Magazine of Management, 10(2), 135-136, 152 (1913). 8. Schreibfeder J. Effective inventory management / John Schreibfeder; Per. with English - 2nd ed. - M .: Alpina Business Books, 2006. - 304 p. [in Ukrainian].

8. Sheremet A D Methods of financial analysis of commercial organizations [Electronic resource] / A D Sheremet, E V Негашев. - М., 2008. - Access mode: http://www.alleng.ru/d/econfin/econ-fin322.htm 7. Financial statements

9. Harris F. W. «How Many Parts To Make At Once» Factory / Harris F. W. // The Magazine of Management, 10 (2), 135-136, 152 (1913) [in Ukrainian].

10. Bogatska NM The essence, purpose and objectives of inventory management - one of the modern aspects of the retail enterprise // Coll. Science. DNU Ave. Issue 191. - Dn .: 2008. - P.180-186[in Ukrainian].

11. Buzak, N. Estimation of inventories as an element of accounting policy of a commercial enterprise / N. Buzak // Economic analysis. - 2011. - № 9. - P. 48-50.

12. Bezginova LI Commodity stocks of the enterprise: essence and their composition / LI Bezginova, KS Olinichenko // Bulletin of ISU. Kharkiv. Economic sciences: coll. Science. works - H., 2012. - P. 12-21 [in Ukrainian]. 